\title{
Citation analysis of 10-year Islamic economic research papers indexed in dimensions.ai
}

\author{
Muhammad Muhajir Aminy ${ }^{1, *}$, \\ Restu Fahdiansyah ${ }^{2}$, \\ Shofia Mauizotun Hasanah ${ }^{3}$
}

Faculty of Islamic Economics and Business, Mataram State Islamic University, Indonesia ${ }^{1,2,3}$

e-mail: azeer.elkhawarizm@uinmataram.ac.id*

\begin{abstract}
The main objective of this study is to analyze cited papers in terms of the most cited author, journal, article, and institution. All documents are listed on dimensions.ai as the source of papers and containing the keyword "Islamic economics" in the title or abstract of the articles. The research method used in this study is citation analysis. The publication period is 10 years, starting from 2012 to 2021. This study showed that only 264 (19.32\%) of 1,366 published articles were cited at least once by other documents during the observation period. The majority of these items came from Indonesia, with a total of 120 documents (45.4\%). The most cited author is Hafas Furqani with 13 articles (4.9\%), the most cited journal is Jurnal Ekonomi Syariah (JES) with a total of 32 articles (12.1\%), the most cited article is a paper titled "Corporate social responsibility, waqf system, and zakat system as faith-based model for poverty reduction" with its 33 citations, and the most cited institution is Airlangga University in Indonesia with a total of 18 articles (6.8\%). This research also provided a finding that 25 institutions and organizations cite one another in their published articles.
\end{abstract}

Keywords: citation analysis, Islamic economics, dimensions.ai

\begin{abstract}
Abstrak
Penelitian ini bertujuan untuk menganalisis sitasi artikel dari segi penulis, nama jurnal, judul artikel, dan institusi. Semua artikel terdaftar pada dimensions.ai dan mengandung kata kunci "Islamic economics" pada judul maupun abstrak artikel. Metode penelitian menggunakan analisis sitasi. Periode publikasi adalah 10 tahun, yaitu tahun 2012 2021. Penelitian ini menemukan bahwa hanya 264 dari 1,366 artikel yang
\end{abstract}


dipublikasikan tersitasi dengan jumlah minimal satu kali sitasi oleh artikel lain. Mayoritas artikel ini berasal dari Indonesia dengan total 120 dokumen (45.4\%). Penulis terbanyak disitasi adalah Hafas Furqani dengan 13 artikel (4.9\%), jurnal terbanyak disitasi adalah Jurnal Ekonomi Syariah (JES) dengan 32 artikel (12.1\%), judul artikel terbanyak disitasi adalah "Corporate social responsibility, waqf system, and zakat system as faith-based model for poverty reduction" dengan 33 sitasi, dan institusi terbanyak disitasi adalah Universitas Airlangga dengan total 18 artikel (6.8\%). Penelitian ini juga menemukan bahwa ada 25 institusi yang saling melakukan sitasi pada artikel-artikel mereka.

Kata kunci: analisis sitasi, ekonomi Islam, dimensions.ai

\section{INTRODUCTION}

Islamic economics has a variety of definitions derived from the era of neoclassical economics which began in the twentieth century. According to Mannan (1986), Islamic economics is a social science that examines the economic issues of a population infused with Islamic principles. Islamic economics also investigates the well-being attained by managing the earth's resources on the basis of collaboration and participation (Khan 1994). Meanwhile, Chapra (2001) stated that Islamic economics can be defined as the branch of knowledge that aids in the realization of human well-being through the allocation and distribution of scarce resources in accordance with Islamic teachings while not unduly restricting individual freedom or perpetuating macroeconomic and ecological imbalances.

Islamic economics should be evaluated in terms of its bibliometric indicators as a new topic of study. By analyzing these indicators, we can create a map of the studies conducted by Muslim scholars in various nations. This is necessary because visualization of Islamic economic studies will aid future research by providing statistics on the most frequently referenced papers, authors, nations, and institutions or organizations. Currently, there are less studies devoted to this subject.

Citation analysis is a systematic examination of citations, references, or footnotes to identify quantitative characteristics such as authorship pattern, topic connections, influence, and research trends and to assess performance (Martyn, 1975). Citation analysis is a popular technique in bibliometrics for determining connections between authors or their works. (Chikate, R.V. \& Patil, S.K, 2008).

Dimensions.ai is a database of linked information that depicts the research life cycle in more detail than previous systems (Herzog, C., and Konkiel, S., 2019). Dimensions currently contains 9 million datasets with a total of 121 million articles, demonstrating how comprehensive dimensions' database is as a data collection of research and publishing information.

This study was conducted to investigate cited papers in the field of Islamic economics during the period of 2012 to 2021. It may help librarians, LIS professionals, as well as Islamic economic researchers in their works related to Islamic economic field.

\section{LITERATURE REVIEW}

Several studies using citation analysis have been conducted by researchers across the countries. Anjuma Saikia and Utpal Saikia (2020) investigated 13,057 citations attached to the 34 Doctoral theses in Chemistry submitted to Dibrugarh University, 
Assam for a Ph.D degree between 2015 and 2019. According to the study's results, 44.93 percent of the total number of 10,446 journal citations are by more than three authors, followed by two authors with 22.83 percent and multiple written papers with 19.30 percent.

In other research, Dez-Martn et al. (2021) investigated bibliometric co-citations to determine the most active research areas in organizational legitimacy, their subdisciplinary composition, patterns of interrelationship, the most influential subject matters, and transformative discoveries. As interest in the relationship between organizational legitimacy and survival increases, the number of publications in the area makes it difficult to keep up of the many lines of study.

Hota et al. (2020) analyzed 1,296 papers containing 74,237 cited references and uncover the structure, or intellectual base, of research on social entrepreneurship by employing methods of citation analysis, document co-citation analysis, and social network analysis. They identify nine different clusters of social entrepreneurship research that represent the field's conceptual structure. The findings offer a comprehensive view of the subject of social entrepreneurship, identifying important publications and analyzing academic communication between these works.

Handoko (2020) found that Indonesian writers' research in the area of IEF has grown quickly, with widespread cooperation. Halal tourism has been one of the most popular research subjects in recent years, and it is a promising area for future study. Furthermore, the findings revealed that IEF materials were frequently utilized as references.

Mohammad Hassanzadeh and Samira Sadat Saber (2020) discovered in their study that the trend of Tarbiat Modares University's scientific outputs increased from 1988 to 2019, with the highest production in 2019 totaling 2,636 papers. The citation trend rose until 2011, then decreased. The majority of national collaborations were with Islamic Azad University and the University of Tehran, as well as international cooperation with the United States. The cluster depicted the most significant publications in the area of Chemistry. This research assists university administrators in better planning scientific growth.

M.T.M. Sithas and H.A.K.N.S. Surangi (2021) examined 174 publications on ethnic minority business published between 2010 and 2020. Citation analysis was used to evaluate research articles in order to identify and categorize the main areas of ethnic minority entrepreneurship that are presently being focused on and investigated by the research community.

Sandip B Khandare and Shashank S Sonwane (2021) studied citations of Dr. Babasaheb Ambedkar Marathwada University, Aurangabad Economics Ph.D. theses for the application of Bradford's Law of Scattering and the Leimkuhler model. Citations of Ph.D. theses in Economics from 1967 to 2017 were used to compile the statistics. During the research period, 319 Ph.D. theses earned a total of 30,611 citations. 7,750 of the 30,611 citations are journal citations. A ranked list of journals was created, and it was discovered that 'Economic and Political Weekly' was the most prolific publication, publishing 1076 total articles (13.88 percent). As a result, the connection between the zones and the data does not technically match Bradford's rule of scattering, but it does verbally. The Leimkuhler model is evaluated, and it is discovered that the data for Bradford multiplier $\mathrm{k}=12.42$ does not fit in the current data set. 


\section{METHOD}

The research method used in this study was citation analysis. Citation analysis may categorize cited publications based on authors, journals, total citations, organizations or institutions, and even the authors' nations. Researchers may identify the top referenced articles in a collection by categorizing all of those issues.

The dataset in this study was obtained by opening the DIMENSIONS indexing website through its URL link www.dimensions.ai, typing the keyword "Islamic economics" for articles title or abstract in the search box, sorting the observed years and publication type, and exporting all the search results into a dataset in the format of ".csv". The publication period in this study is 10 years, starting from 2012 to 2021.

This research used two computer applications, namely Microsoft Excel and VOSviewer. Microsoft Excel is utilized to categorize the findings, while VOSviewer is a useful research tool for citation analysis from the acquired dataset.

The number of articles used in this research is 1,366 , while the cited articles with a minimum of one citation are only 264 papers $(19.32 \%)$. These papers were published in a variety of journals from across the world.

\section{RESULT AND DISCUSSION}

\section{Trends in the year of publications}

The number of publications with the keyword "Islamic economics" increased in 10 years from 2012 to 2021 . In 2012 there were only 29 articles, while in the last of 2020 there were 300 of them. Unfortunately, the articles produced in 2021 have only decreased to 128 articles. The number of publications this year could be higher than in 2020 since the year 2021 is still running.

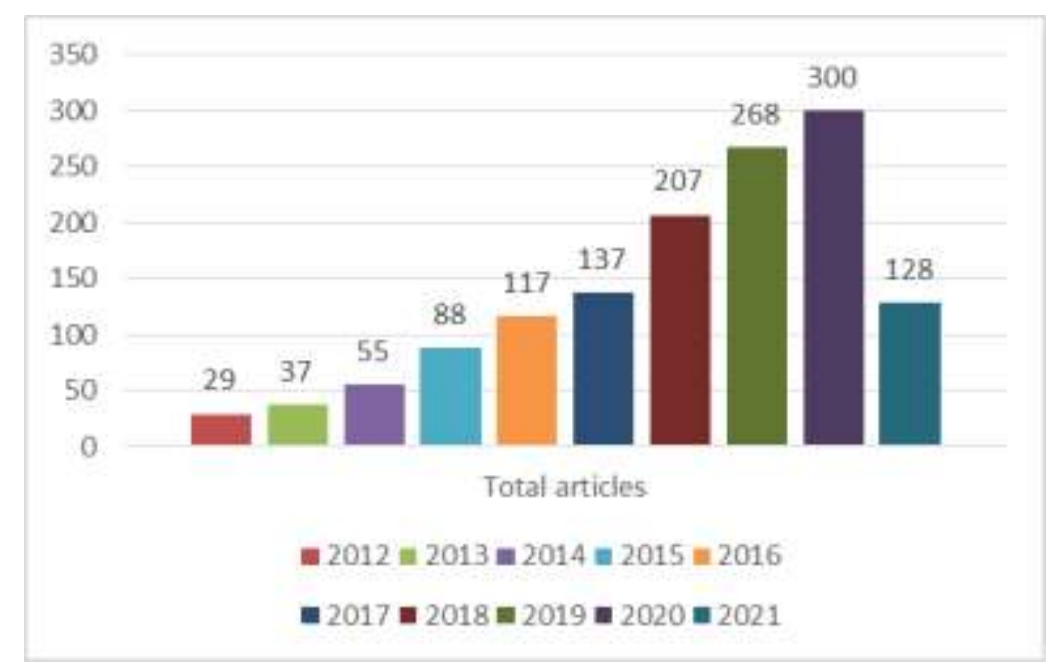

Figure 1. The trend of publications with the keyword "Islamic economics" during 2012-2021

\section{Analysis of the cited articles}

The density of the name "Indonesia" in Figure 2 showed that most articles with the keyword "Islamic economics" were published in Indonesia. The number of cited articles from this region reached 120 (45.4\%) of the total, followed by Malaysia with 43 articles (16.28\%), the United Kingdom with 11 articles (4.16\%), the United States with 
10 articles (3.78\%), Pakistan and Saudi Arabia with 8 articles (3.03\%) each, and other 30 countries.

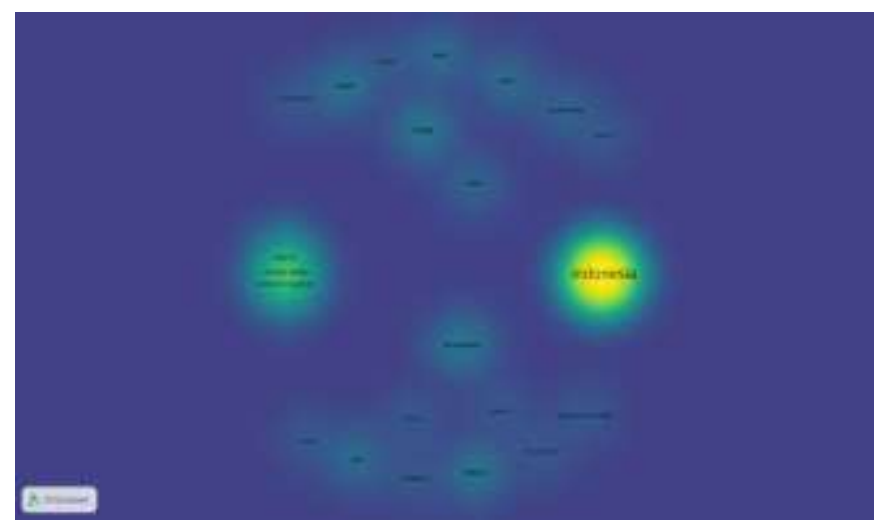

Figure 2. Density visualization of countries of origin

There are 11 authors with a number of cited articles of more than 5 papers. The most cited author is Hafas Furqani with 13 articles, followed by Ahmad Ubaidillah with 10 documents, Masudul Alam Choudhury with 8 papers, Necati Aydin with 6 articles, Ismaulina with 6 articles, and 5 other authors with 5 articles each, as seen in Table 1. The total number of authors with 1-4 cited articles was 312 people, while all cited authors reached 323 people.

Table 1. The most cited authors with cited papers more than 5 documents during 2012-2021

\begin{tabular}{llc}
\hline No. & Name of the cited authors & Total cited papers \\
\hline $\mathbf{1}$ & Hafas Furqani & 13 \\
$\mathbf{2}$ & Ahmad Ubaidillah & 10 \\
$\mathbf{3}$ & Masudul Alam Choudhury & 8 \\
$\mathbf{4}$ & Mohammad Ghozali & 7 \\
$\mathbf{5}$ & Necati Aydin & 6 \\
$\mathbf{6}$ & Ismaulina & 6 \\
$\mathbf{7}$ & Rahmad Hakim & 5 \\
$\mathbf{8}$ & Aan Jaelani & 5 \\
$\mathbf{9}$ & Shinsuke Nagaoka & 5 \\
$\mathbf{1 0}$ & Nurhadi & 5 \\
$\mathbf{1 1}$ & Tika Widiastuti & 5 \\
Total authors with $\mathbf{1 - 4}$ cited papers: $\mathbf{3 1 2}$ people &
\end{tabular}

source: processed data, 2021

264 articles as observed papers in this study were published by 141 journals over the countries. The most cited journal is Jurnal Ekonomi Syariah (JES), with a total of 32 documents, followed by Share Jurnal Ekonomi dan Keuangan Islam with 24 documents as the $2^{\text {nd }}$ rank, Islamic Economic Studies in the $3^{\text {rd }}$ position with 17 articles, Jurnal Ilmiah Ekonomi totaling 16 articles, Al-Iqtishad Journal of Islamic Economics with 15 papers, Humanomics with 13 articles, Al-Falah Journal of Islamic Economics totaling 13 documents, Hunafa Jurnal Studia Islamika with 12 papers, International Journal of Islamic and Middle Eastern Finance and Management with 11 articles, Economica 
Jurnal Ekonomi Islam with a total of 11 documents, and 3 other journals with 10 papers each. Total journals with 1-9 articles reached 128 journals. 9 of the top 13 journals with more than 10 cited papers are the publishers from Indonesia. Details can be seen in the following table.

Table 2. Cited journals with cited articles more than 10 documents during the study period

\begin{tabular}{llc}
\hline No. & Name of journals & Total cited documents \\
\hline $\mathbf{1}$ & Jurnal Ekonomi Syariah (JES) & 32 \\
$\mathbf{2}$ & Share Jurnal Ekonomi dan Keuangan Islam & 24 \\
$\mathbf{3}$ & Islamic Economic Studies & 17 \\
$\mathbf{4}$ & Jurnal Ilmiah Ekonomi Islam & 16 \\
$\mathbf{5}$ & Al-Iqtishad Journal of Islamic Economics & 15 \\
$\mathbf{6}$ & Humanomics & 13 \\
$\mathbf{7}$ & Al-Falah Journal of Islamic Economics & 12 \\
$\mathbf{8}$ & Hunafa Jurnal Studia Islamika & 11 \\
$\mathbf{9}$ & International Journal of Islamic and Middle Eastern & 11 \\
& Finance and Management & 10 \\
$\mathbf{1 0}$ & Economica Jurnal Ekonomi Islam & 10 \\
$\mathbf{1 1}$ & Ahkam Jurnal Ekonomi Islam & 10 \\
$\mathbf{1 2}$ & Islamiconomic Jurnal Ekonomi Islam & \\
$\mathbf{1 3}$ & Journal of King Abdulaziz University-Islamic & \\
& Economics & \\
\hline
\end{tabular}

Total journals with 1-9 cited documents: 128 journals

source: processed data, 2021

The most cited article is a paper titled "Corporate social responsibility, waqf system, and zakat system as faith-based model for poverty reduction" published in 2014 with 33 citations, followed by a paper titled "A synthesis of theoretical and empirical research on sukuk" published in 2015 with a total of 29 times cited by other documents, the $3^{\text {rd }}$ rank was occupied by "Islam, inequality, and pre-industrial comparative development" published in 2016 received 19 citations. The $4^{\text {th }}$ and $5^{\text {th }}$ positions were occupied by two papers titled "Developing a conceptual framework to appraise the corporate social responsibility performance of Islamic banking and finance institutions" and "Hoarding versus circulation of wealth from the perspective of maqasid al-shariah" published in 2013 and 2014 with 17 citations each, and followed by the remaining 259 papers. Total articles with 1-9 times cited are 250 documents.

Table 3. Cited articles with the keyword "Islamic economics" from 2012 to 2021

\begin{tabular}{llcc}
\hline No. & Title of articles & $\begin{array}{l}\text { Total } \\
\text { citations }\end{array}$ & $\begin{array}{c}\text { Year } \\
\text { publications }\end{array}$ \\
\hline $\mathbf{1}$ & $\begin{array}{l}\text { Corporate social responsibility, waqf system, and zakat } \\
\text { system as faith-based model for poverty reduction }\end{array}$ & 33 & 2014 \\
$\mathbf{2}$ & $\begin{array}{l}\text { A synthesis of theoretical and empirical research on } \\
\text { sukuk }\end{array}$ & 29 & 2015 \\
$\mathbf{3}$ & $\begin{array}{l}\text { Islam, inequality, and pre-industrial comparative } \\
\text { development }\end{array}$ & 19 & 2016 \\
$\mathbf{4}$ & Developing a conceptual framework to appraise the & 17 & 2013 \\
\hline
\end{tabular}




\begin{tabular}{|c|c|c|c|}
\hline & $\begin{array}{l}\text { corporate social responsibility performance of Islamic } \\
\text { banking and finance institutions }\end{array}$ & & \\
\hline 5 & $\begin{array}{l}\text { Hoarding versus circulation of wealth from the } \\
\text { perspective of maqasid al-shariah }\end{array}$ & 17 & 2014 \\
\hline 6 & $\begin{array}{l}\text { Redefining Islamic economics as a new economic } \\
\text { paradigm }\end{array}$ & 14 & 2013 \\
\hline 7 & $\begin{array}{l}\text { Uniform framework for sukuk al-ijarah - a proposed } \\
\text { model for all madhahib }\end{array}$ & 14 & 2017 \\
\hline 8 & Islamic economics: still in search of an identity & 13 & 2013 \\
\hline 9 & $\begin{array}{l}\text { Critical overview of the history of Islamic economics: } \\
\text { formation, transformation, and new horizons }\end{array}$ & 12 & 2012 \\
\hline 10 & $\begin{array}{l}\text { Islamic economics and Islamic finance in the world } \\
\text { economy }\end{array}$ & 11 & 2017 \\
\hline 11 & $\begin{array}{l}\text { A proposed model for waqf financing public goods and } \\
\text { mixed public goods in Malaysia }\end{array}$ & 10 & 2018 \\
\hline 12 & Exploitation, profit, and the riba-interest reductionism & 10 & 2012 \\
\hline 13 & $\begin{array}{l}\text { The global financial crisis and Islamic finance: a review } \\
\text { of selected literature }\end{array}$ & 10 & 2015 \\
\hline 14 & $\begin{array}{l}\text { Contemporary Islamic economic studies on maqasid } \\
\text { shariah: a systematic literature review }\end{array}$ & 10 & 2017 \\
\hline
\end{tabular}

In this analysis, Airlangga University in Indonesia is the most cited university. It has a total of 18 referenced publications, followed by International Islamic University of Malaya with 14 articles, University of Malaya in third place with 10 papers, Islamic University of Indonesia with 7 articles, 4 other institutions with 6 documents each, University of Muhammadiyah totaling 5 documents, and other 75 institutions with 1-4 cited documents. 7 of 9 most cited institutions with more than 4 cited articles are Indonesia-based universities, while 2 others are Malaysia-based colleges.

Table 4. Cited institutions with more than 4 documents

\begin{tabular}{llc}
\hline No. & Institutions or organizations & Total cited articles \\
\hline $\mathbf{1}$ & Airlangga University & 18 \\
$\mathbf{2}$ & International Islamic University of Malaysia & 14 \\
$\mathbf{3}$ & University of Malaya & 10 \\
$\mathbf{4}$ & Islamic University of Indonesia & 7 \\
$\mathbf{5}$ & Trisakti University & 6 \\
$\mathbf{6}$ & Bandung Islamic University & 6 \\
$\mathbf{7}$ & Diponegoro University & 6 \\
$\mathbf{8}$ & University of Brawijaya & 6 \\
$\mathbf{9}$ & University of Muhammadiyah & 5 \\
\hline
\end{tabular}

Total institutions or organizations with 1-4 cited articles: 75

source: processed data, 2021

Cited papers came from 155 institutions and organizations which are categorized into 135 clusters. 6 clusters consisted of more than one institution or organization. The 
number of institutions in these 6 clusters is 25, implying that 25 institutions and organizations (16.12\%) are citing one another in their publications.

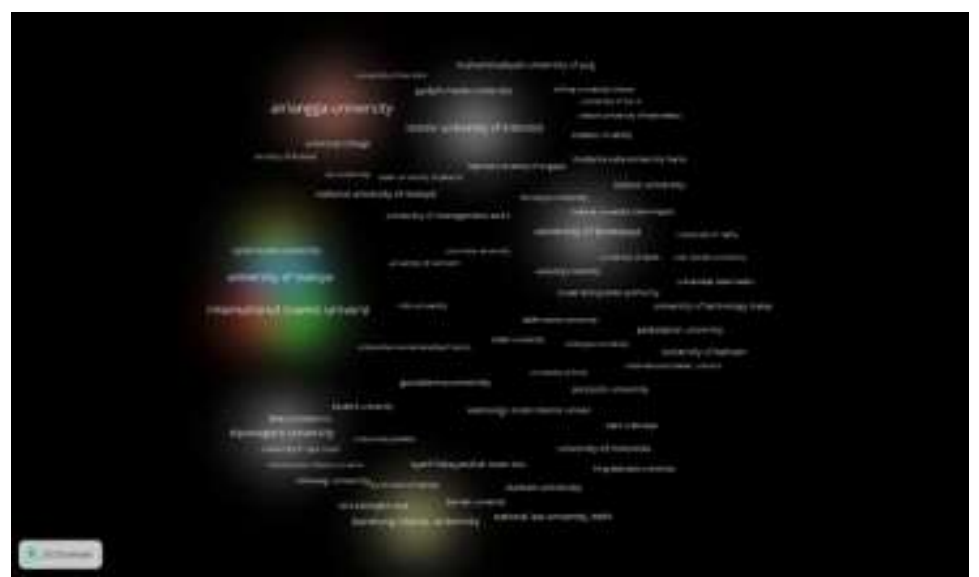

Figure 3. Institutions and organizations clusters of cited articles

6 clusters that consisted of more than one institution and organization are as follows:

Cluster 1: International Centre for Education in Islamic Finance, Kyoto University, La Trobe University, Rennes School of Business, Sultan Qaboos University, Sunway University, and Universitas Islam Negeri Sumatera Utara

Cluster 2: California State University, Comsats University Islamabad, International Islamic University of Malaysia, Universiti Sains Islam Malaysia, University of New Orleans, and University of Science Malaysia

Cluster 3: Hamad bin Khalifa University, International University of Sarajevo, Trisakti University, Universitas Paramadina, University of KwazuluNatal, and University of Malaya

Cluster 4: Syiah Kuala University, Universitas Muhammadiyah Malang, and University of Brunei Darussalam

Cluster 5: $\quad$ Alfaisal University and King Saud University

Cluster 6: $\quad$ Coventry University and Pedagogical University

\section{CONCLUSION}

Citation analysis is very beneficial for analyzing cited publications and finding the most cited author, journal, article, and institution. The number of articles with the keyword "Islamic economics" published in various journals and indexed in dimensions.ai increased during 2012-2021. The total number of published articles during the observed period reached 1,366 and only $264(19.32 \%)$ of them were cited a minimum of once. Most of them were published in Muslim countries with the majority coming from Indonesia, totaling 120 articles (45.4\%). The most cited author is Hafas Furqani with a total of 13 articles (4.9\%), while the most cited journal is Jurnal Ekonomi Syariah (JES) with a total of 32 articles (12.1\%). Furthermore, the most cited article is a paper titled "Corporate social responsibility, waqf system, and zakat system as faith-based model for poverty reduction" with a total of 33 citations, and the most cited institution is Airlangga University in Indonesia with 18 articles (6.8\%). This study also revealed that 25 institutions and organizations classified into 6 clusters citing one another in their publications. 
The results are expected to make contributions and become more beneficial to librarians, LIS professionals, lecturers, and researchers concerned with Islamic economics for their considerations on gathering literature related to the field. This study has practical and managerial implications to librarians, LIS professionals, lecturers, and researchers. Librarians and LIS professionals can select to deposit articles from the best journals into their institutional electronic or digital libraries and information centres for college students' needs. Lecturers can recommend the articles as learning materials for their students when teaching in class. Researchers can use the results as recommendations to publish their manuscripts and get references for their current and further studies.

\section{LIMITATIONS OF THE STUDY}

There are two limitations to this study. First, this study only adopted the keyword "Islamic economics" as part of the title or abstract of the observed articles. Research topics are not considered; thus, it is not impossible that numerous articles on irrelevant topics in Islamic economics were also observed in this study. Second, the total of citations is only quantified within articles provided in the dataset. Meaning, the number of citations of one document in this paper does not reflect its actual count. The document might be cited by other articles outside of the dataset.

\section{REFERENCES}

Chapra, M. U. (2001). What is Islamic Economics? Islamic Development Bank. Islamic Research and Training Institute, 33.

Chikate, R.V. \& Patil, S.K. (2008) Citation analysis of theses in library and information science submitted to University of Pune: A pilot study. Library. Philosophy and Practice.

Díez-Martín, F., Blanco-González, A., \& Prado-Román, C. (2021). The intellectual structure of organizational legitimacy research: a co-citation analysis in business journals. Review of Managerial Science, 15(4), 1007-1043.

Handoko, L. H. (2020). Bibliometric analysis and visualization of Islamic economics and finance articles indexed in Scopus by Indonesian authors. Science Editing, 7(2), 169-176.

Hassanzadeh, M., \& Saber, S. S. A Citation Analysis of the Scientific Publication of Universities: A Study of Tarbiat Modares University during 1988-2019.

Herzog C., Hook D., dan Konkiel S., 2020. Dimensions: Bringing down barriers between scientometricians and data. Quantitative Science Studies. Vol. 1, No.1, 387-395. doi: https://doi.org/10.1162/qss_a_00020

Hota, P. K., Subramanian, B., \& Narayanamurthy, G. (2020). Mapping the intellectual structure of social entrepreneurship research: A citation/co-citation analysis. Journal of Business Ethics, 166(1), 89-114.

John Martyn, (1975) "CITATION ANALYSIS", Journal of Documentation, 31(4) 290297, https://doi.org/10.1108/eb026610

Khan, M. A. (1994). An introduction to Islamic economics (Vol. 15). International Institute of Islamic Thought (IIIT).

Khandare, S. B., \& Sonwane, S. S. (2021). Citation Analysis of Economics Ph. D. Theses of Dr. Babasaheb Ambedkar Marathwada University Aurangabad: A Scientometric Study. Journal of Indian Library Association, 57(2), 50-59. 
Mannan, M. A. (1986). Islamic economics: theory and practice; (foundations of Islamic economics). Westview Press.

Saikia AS, A., \& Saikia US, U. (2020). Citation analysis of doctoral theses submitted to The Departement of Chemistry, Dibrugarh University, Assam, India. Library Philosophy and Practice (e-journal). 4525.

Sithas, M. T. M., \& Surangi, H. A. K. N. S. (2021). Systematic Literature Review on Ethnic Minority Entrepreneurship: Citation and Thematic Analysis. Journal of Ethnic and Cultural Studies, 8(3), 183-202. 